\title{
Changing Mechanicals Characteristiques of Cementitious Materials Using Titanium Dioxide
}

\author{
Valéry Kouandété Doko', Sena Peace Hounkpe ${ }^{2}$, Smith Oyebissi Kotchoni ${ }^{3}$, \\ Li Hui ${ }^{3}$, Abbas Tiambo Datchossa ${ }^{*}$ \\ ${ }^{1}$ Laboratory of Applied Energetics and Mechanics (LAEM), EPAC, UAC, Cotonou, Benin \\ ${ }^{2}$ Loboratory of Water Technical Sciences, UAC, Cotonou, Benin \\ ${ }^{3}$ Harbin Institute of Technology, Harbin, China \\ Email: *datchossatiamboabbas@gmail.com
}

How to cite this paper: Doko, V.K. Hounkpe, S.P., Kotchoni, S.O., Hui, L. and Datchossa, A.T. (2021) Changing Mechanicals Characteristiques of Cementitious $\mathrm{Ma}$ terials Using Titanium Dioxide. Materials Sciences and Applications, 12, 297-313. https://doi.org/10.4236/msa.2021.126020

Received: March 19, 2021

Accepted: June 27, 2021

Published: June 30, 2021

Copyright (c) 2021 by author(s) and Scientific Research Publishing Inc. This work is licensed under the Creative Commons Attribution International License (CC BY 4.0).

http://creativecommons.org/licenses/by/4.0/

\begin{abstract}
Since many years ago, the substitution of cement by other cementitious supplementary elements has being a purpose for many researchers. This is to reduce the impact of producing cement on our environment. In this article, we are interested in the possibility of substituting cement with titanium dioxide and titanium dioxide + fly ash. To achieve this purpose, we have manufactured mortars and cement pastes specimens with different rates of replacement of cement by titanium dioxide $(0 \%, 0.1 \%, 1 \%)$ on the one hand and titanium dioxide + fly ash on the overhand. The flexural and compressive strength of each specimen has been determined.
\end{abstract}

\section{Keywords}

Silicates, Flexural Strength, Compressive Strength, Cement, Titanium Dioxide

\section{Introduction}

Cement can be described as a crystalline compound of calcium silicates and other calcium compounds having hydraulic properties [1]. The four major compounds that constitute cement (Bogue's Compounds) are Tricalcium silicate, abbreviated as $C_{3} S$, Dicalcium silicate $\left(C_{2} S\right)$, Tricalcium aluminate $\left(C_{3} A\right)$, Tetracalcium aluminoferrite $\left(\mathrm{C}_{4} \mathrm{AF}\right)$ where $\mathrm{C}$ stands for $\mathrm{CaO}, \mathrm{S}$ stands for $\mathrm{SiO}_{2}$, A stands for $\mathrm{Al}_{2} \mathrm{O}_{3}$ and $\mathrm{F}$ for $\mathrm{Fe}_{2} \mathrm{O}_{3}$ [2] [3]. Cement is the main constituent of the concrete, the widely used in structures, from buildings to factories, from bridges to airports. This makes concrete to be one of the most investigated materials of the 21 st century.

The increased use of cement is essential in attaining a higher compressive 
strength. But, cement is a major source of pollution [4] [5]; It is for this reason that several authors have been interested in finding new materials to limit the use of cement [6]. It is in this sense that [7] designed concrete based on volcanic ash and found mechanical properties similar to those of ordinary cement concrete.

At the same time, nanomaterials are showing their interest, with a large number of researchers looking to them as an alternative.

Moreover, Hossain and al. have shown that the use of nanomaterials by replacement of a proportion of cement can lead to a rise in the compressive strength by developing supplementary chemical reactions [8] of the concrete as well as a check to pollution.

In this article, we are interested in improving the crack resistance, improving the mechanical properties of concrete using titanium dioxide and fly ash.

\section{Materials and Methods}

\subsection{Materials}

\subsubsection{General}

This chapter is concerned with the details of the properties of the materials used, the method followed to design the experiment and the test procedures followed. The theory is supplemented with a number of pictures to have a clear idea of the methods.

\subsubsection{Materials Properties}

The materials used to design the mix for $\mathrm{C}_{30}, \mathrm{C}_{40}$, grade of concrete is cement, fly ash grade II, sand, coarse aggregate, water, and Titanium dioxide $\left(\mathrm{TiO}_{2}\right)$ admixture. The properties of these materials are presented below.

\subsubsection{Properties of Cement}

Ordinary Portland cement (Chinese Standard GB 8076-2008) Classified as 42.5R was applied in This Study. Chemical Composition, Mineral Composition, as well as Physical Performance of the cement, are shown in Table 1. The contents of oxides were measured Through X-Ray Fluorescence. The Content of F-Cao was analyzed by the Franke Method. The mineral phases were calculated by The Bogue Method.

\subsubsection{Fly Ash}

The disposal of fly ash poses increasingly difficult problems for many urbanized regions. A viable solution to the problem is reclamation of Fly ash for Civil Engineering applications. Previous researchers showed that fly ash is a potential source of construction material and soil stabilizer. Although it is one of the lowest

Table 1. Chemical and mineral compositions of cement (Wt/\%).

\begin{tabular}{ccccccccccccccc}
\hline \multicolumn{4}{c}{ Chemical Composition (\%) } & \multicolumn{4}{c}{ Mineral Composition (\%) } \\
\hline $\mathrm{SiO}_{2}$ & $\mathrm{Fe}_{2} \mathrm{O}_{3}$ & $\mathrm{Al}_{2} \mathrm{O}_{3}$ & $\mathrm{CaO}$ & $\mathrm{MgO}$ & $\mathrm{SO}_{3}$ & $\mathrm{FcaO}$ & $\mathrm{Cl}^{-}$ & $\mathrm{Na}_{2} \mathrm{Oeq}$ & LOSS & $\mathrm{C}_{3} \mathrm{~S}$ & $\mathrm{C}_{2} \mathrm{~S}$ & $\mathrm{C}_{3} \mathrm{~A}$ & $\mathrm{C}_{4} \mathrm{AF}$ \\
\hline 20.560 & 3.230 & 4.600 & 62.560 & 2.570 & 2.950 & 0.870 & 0.011 & 0.530 & 2.040 & 57.340 & 18.900 & 6.470 & 11.250
\end{tabular}


cost and most widely used materials in the world, cement raises many concerns for the environment and human health. Many studies have been conducted with the aim of reducing the cost of cement for soil stabilization; one option is to partially replace cement with waste materials such as fly ash. In this study, we used fly ash grade II.

\subsubsection{Properties of Water}

Tap water was used in this experiment. The properties are assumed to be same as that of normal water. Specific gravity is taken as 1.00. Pure water (deionized water) was used to make mortar specimen and cement paste.

\subsubsection{Properties of Titanium Oxide, Anatase}

The average size of Titanium Oxide was $25 \mathrm{~nm}$ with $99.8 \%$ metals basis from Particle Size Analyzer.

\subsubsection{Properties of Cement Paste and Mortar}

Cement paste and mortar are prepared with a water/cement ratio (w/c) of 0.32 , using a blade-type high shear blender. Before mixing, polycarboxylate superplasticizers (PCE) solution was prepared with deionized water. With the addition of polycarboxylate superplasticizers (PCE) solution dosage $0.3 \%$ b.w.c., Cement paste was mixed for $2 \mathrm{~min}$ at low speed and then $2 \mathrm{~min}$ at high speed. The table below showed the proportion and quantities of material used by following Chinese standard.

\subsection{Methods}

\subsubsection{Mix Calculations for Cement Paste}

The design of each mix began with constant paste content (water + cement + supplementary cementitious materials) of 0.32 by weight of the total mix. The weight of cement and water were adjusted based on the specified water to binder ratio. The remainder of the mixture consisted of sand. Superplasticizer and air entraining agent were added based on experience and trial mixing prior to beginning the test program. Table 2, Table 3 below detail the actual weights of the mixture components.

\subsubsection{Mix Calculations for Mortar}

The design of each mix began with constant paste content (water + cement + supplementary cementitious materials) of 0.32 by weight of the total mix. The

Table 2. Mixture proportions with W/C ratio 0.32 for cement paste without fly ash.

\begin{tabular}{ccccccc}
\hline \multirow{2}{*}{ Cement Paste type } & water $(\mathrm{g})$ & Cement $(\mathrm{g})$ & $\begin{array}{c}\text { Titanium } \\
\text { dioxide } \mathrm{TiO}_{2}\end{array}$ & Water reducing & agent $(\mathrm{g})$ & Test pieces \\
\hline Pure Cement Paste & $\mathrm{PO}$ & 1664 & 5200 & & 5.4 & 12 \\
& $\mathrm{~T} 01$ & 1664 & 5200 & 5.2 & 5.4 & 12 \\
$\begin{array}{c}\text { Nano Titanium } \\
\text { dioxide } \mathrm{TiO}_{2}\end{array}$ & $\mathrm{~T} 1$ & 1664 & 5200 & 52 & 5.4 & 12 \\
\multicolumn{1}{c}{ Total dosage } & 4992 & 15,600 & 57.2 & 16.2 & 36 \\
\hline
\end{tabular}


Table 3. Mixture proportions with W/C ratio 0.32 for cement paste content fly ash.

\begin{tabular}{cccccccc}
\hline \multicolumn{2}{c}{ Cement Paste type } & water $(\mathrm{g})$ & Cement $(\mathrm{g})$ & Fly Ash & $\mathrm{TiO}_{2}$ & $\begin{array}{c}\text { Water reducing } \\
\text { agent }(\mathrm{g})\end{array}$ & Test pieces \\
\hline Pure Cement Paste & $\mathrm{P} 0$ & 1664 & 4160 & 1040 & & 5.4 & 12 \\
Nano Titanium & $\mathrm{T} 01$ & 1664 & 4160 & 1040 & 5.2 & 5.4 & 12 \\
dioxide $\mathrm{TiO}_{2}$ & $\mathrm{~T} 1$ & 1664 & 4160 & 1040 & 52 & 5.4 & 12 \\
Total dosage & 4992 & 12,480 & 3120 & 57.2 & 16.2 & 36 \\
\hline
\end{tabular}

weight of cement and water was adjusted based on the specified water to binder ratio. The remainder of the mixture consisted of sand. Superplasticizer and air entraining agent were added based on experience and trial mixing prior to beginning the test program. Table 4, Table 5 below detail the actual weights of the mixture components.

\subsubsection{Test Procedures}

\section{Curing Regimens}

The specimens remained in their molds for 24 hours at room temperature, $25^{\circ} \mathrm{C}$. The Specimens tested were generally curing with air cured at $25^{\circ} \mathrm{C}$ and $\mathrm{RH}$ $92 \%$ for 3 days, 7 days and 28 days.

\subsubsection{Testing}

Testing procedures used to evaluate compressive strength, flexural strength and interatomic behaviors between cement and titanium dioxide are presented in this section.

\subsubsection{SEM Test}

Scanning Electron Microscope (SEM) test is performed by technical experts, and thus it is not explained here and only the results are presented in the result and discussion section.

\subsubsection{Flexural Strength Test for Mortar and Cement Paste}

Flexural testing machine Reference number YAW-300 was used. Flexural strength was evaluated according to Chinese standard with the software Super Test version 8 and the load rate was $50 \mathrm{~N} / \mathrm{s}$. Prismatic specimens with dimensions of 40 $\mathrm{mm} \times 40 \mathrm{~mm} \times 160 \mathrm{~mm}$ were loaded using a third point loading setup across their strong axis. Three specimens from each batch were tested at an age of 3, 7, and 28 days and the mean Flexural strength of three specimens is considered as the Flexural strength of the specified category.

\subsubsection{Compressive Strength Test for Mortar and Cement Paste}

Compressive testing machine Reference number YAW-300 was used after 3, 7, and 28 days of curing with surface dried condition as per Chinese Standard. The compressive strength of specimens is determined with the software Super Test version 8 and the load rate was $2.4 \mathrm{KN} / \mathrm{s}$. Three specimens are tested for typical category and the mean compressive strength of three specimens is considered as the compressive strength of the specified category. 
Table 4. Mixture proportions with W/C ratio 0.32 for mortar discontent fly ash.

\begin{tabular}{cccccccc}
\hline Mortar type & & Water (g) & Cement (g) & Sand (g) & $\mathrm{TiO}_{2}$ & \multicolumn{2}{c}{ Water reducing } \\
agent $(\mathrm{g})$ & Test pieces \\
\hline Pure Mortar & $\mathrm{PO}$ & 576 & 1800 & 5400 & None & 5.4 & 12 \\
& $\mathrm{~T} 01$ & 576 & 1800 & 5400 & 1.8 & 5.4 & 12 \\
$\begin{array}{c}\text { Nano Titanium } \\
\text { dioxide TiO }\end{array}$ & $\mathrm{T} 1$ & 576 & 1800 & 5400 & 18 & 5.4 & 12 \\
Total dosage & 1728 & 5400 & 16,200 & 19.8 & 16.2 & 36 \\
\hline
\end{tabular}

Table 5. Mixture proportions with W/C ratio 0.32 for mortar content fly ash.

\begin{tabular}{|c|c|c|c|c|c|c|c|c|}
\hline \multicolumn{2}{|c|}{ Mortar type } & \multirow{2}{*}{$\begin{array}{c}\text { Water } \\
(\mathrm{g})\end{array}$} & \multirow{2}{*}{$\begin{array}{c}\begin{array}{c}\text { Cement } \\
(\mathrm{g})\end{array} \\
1440\end{array}$} & \multirow{2}{*}{$\begin{array}{c}\text { Fly Ash } \\
\text { (g) }\end{array}$} & \multirow{2}{*}{$\begin{array}{c}\text { Sand }(\mathrm{g}) \\
5400\end{array}$} & \multirow{2}{*}{$\begin{array}{c}\mathrm{TiO}_{2} \\
(\mathrm{~g}) \\
\text { None }\end{array}$} & \multirow{2}{*}{$\begin{array}{c}\text { Water reducing } \\
\text { agent }(\mathrm{g}) \\
5.4\end{array}$} & \multirow{2}{*}{$\begin{array}{c}\text {-Test pieces } \\
12\end{array}$} \\
\hline Pure Mortar & $\mathrm{PO}$ & & & & & & & \\
\hline \multirow{2}{*}{$\begin{array}{c}\text { Nano Titanium } \\
\text { dioxide } \mathrm{TiO}_{2}\end{array}$} & T01 & 576 & 1440 & 360 & 5400 & 1.8 & 5.4 & 12 \\
\hline & $\mathrm{T} 1$ & 576 & 1440 & 360 & 5400 & 18 & 5.4 & 12 \\
\hline \multicolumn{2}{|c|}{ Total dosage } & 1728 & 4320 & 1080 & 16,200 & 19.8 & 16.2 & 36 \\
\hline
\end{tabular}

\section{Presentation of Results and Analysis}

This chapter is concerned with the presentation of results of the experiments carried out towards the objective of the article.

\subsection{Scanning Electron Microscope (SEM) Images and EDS Results}

Take a small piece of the sample to after full salt soaked in ethanol termination of hydration, then $50^{\circ} \mathrm{C}$ drying in the oven for $24 \mathrm{~h}$. The surface morphology and element distribution of cement were analyzed by SEM and EDS energy spectrum analysis. Through SEM, it can be seen that the surface morphology of the sample is shown in Figure 1 and Figure 2 after substituting cement by different sizes of Nano-materials in the case of an investigation.

\subsubsection{Comparison of SEM Micrographs}

Figure 1 shows the FESEM micrograph of control mortar specimen. In this figure, it can be clearly seen that the C-S-H gel is distributed with lots of empty spaces between the lumps. The lumps can be $\mathrm{Ca}(\mathrm{OH})_{2}$ which declines the Interfacial Transition Zone (ITZ) [9]. The microstructure looks to contain mainly formless substances.

Figure 2 shows the FESEM micrograph of the mortar specimen with Titanium Dioxide $0.1 \%$ b.w.c. A uniform microstructure with very little void can be seen. The absence of $\mathrm{Ca}(\mathrm{OH})_{2}$ crystals indicates that $\mathrm{CNT}$ has reacted with $\mathrm{Ca}(\mathrm{OH})_{2}[10]$ and converted it into C-S-H gel [11].

\subsubsection{Comparison of Chemical Composition of the Specimen}

Figure 3 and Table 6 show the comparative chemical arrangement of mortar specimen deprived of Titanium Dioxide. High concentration of calcium is due to the formation of $\mathrm{Ca}(\mathrm{OH})_{2}$ crystals which declines the ITZ [9]. 


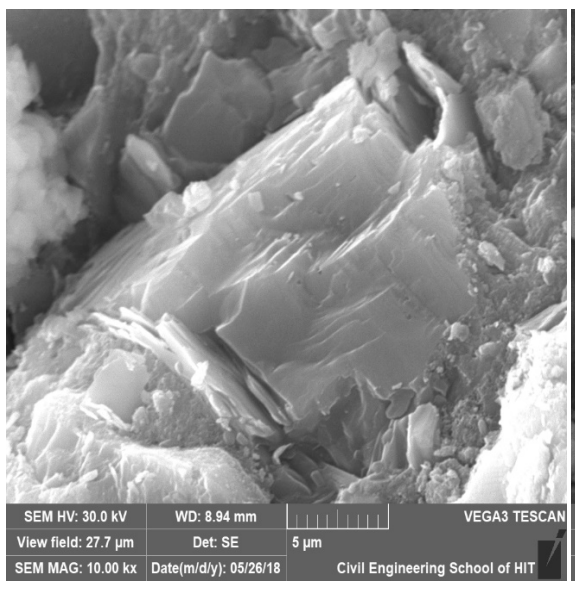

(a)

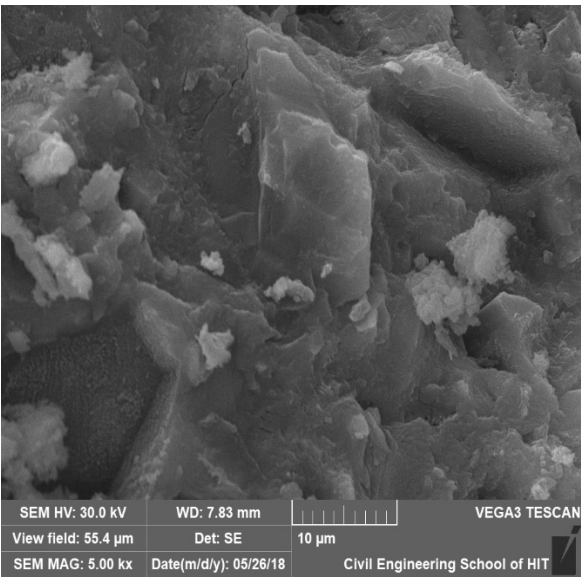

(b)

Figure 1. SEM image of control specimen with different magnification. (a) at magnification $5 \mathrm{~nm}$; (b) at magnification $10 \mathrm{~nm}$.

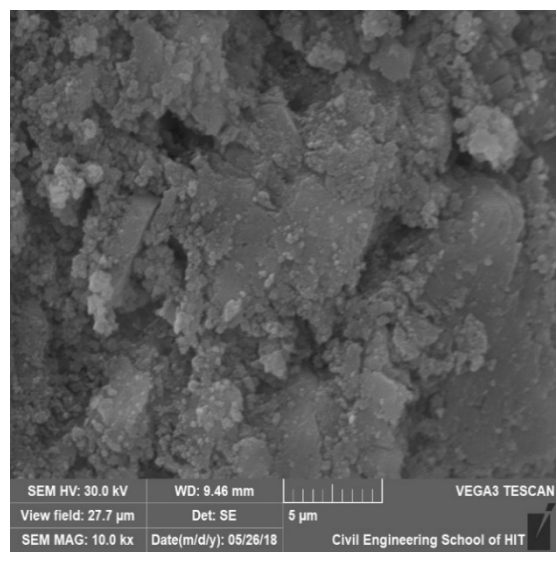

(a)

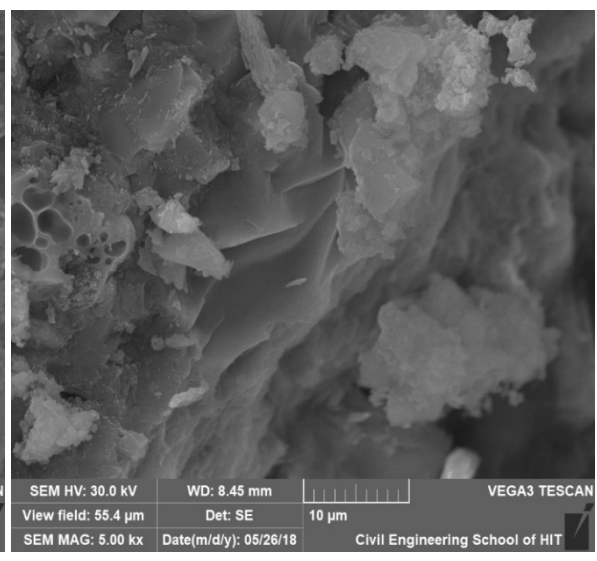

(b)

Figure 2. SEM image of Tiatanium Dioxide specimen with different magnification. (a) at magnification $5 \mathrm{~nm}$; (b) at magnification $10 \mathrm{~nm}$.

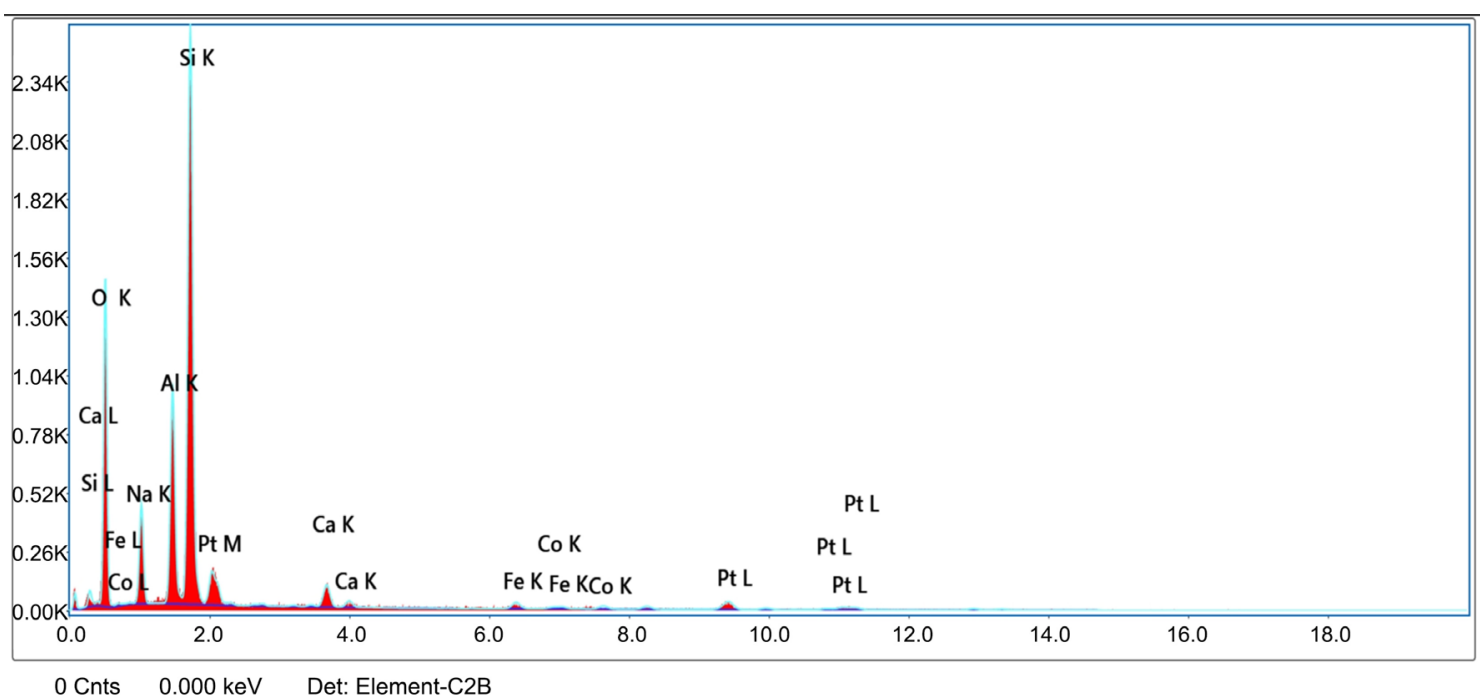

Figure 3. Relative chemical composition for the control specimen. 
Table 6. Relative smart quant results for control specimen.

\begin{tabular}{ccccccccc}
\hline Element & Weight (\%) & Atomic (\%) & Net Int. & Error (\%) & K ratio & Z & A & F \\
\hline O K & 42.65 & 56.97 & 289.36 & 9.26 & 0.1162 & 1.0578 & 0.2576 & 1.0000 \\
$\mathrm{NaK}$ & 11.16 & 10.37 & 102.86 & 10.70 & 0.0272 & 0.9703 & 0.2505 & 1.0014 \\
$\mathrm{AlK}$ & 11.52 & 9.13 & 251.72 & 7.92 & 0.0465 & 0.9552 & 0.4215 & 1.0035 \\
$\mathrm{SiK}$ & 29.13 & 22.17 & 718.44 & 7.08 & 0.1239 & 0.9784 & 0.4344 & 1.0011 \\
$\mathrm{CaK}$ & 1.35 & 0.72 & 37.36 & 9.89 & 0.0101 & 0.9339 & 0.7916 & 1.0164 \\
$\mathrm{FeK}$ & 0.51 & 0.20 & 12.86 & 24.39 & 0.0047 & 0.8423 & 0.9891 & 1.1015 \\
$\mathrm{CoK}$ & 0.15 & 0.05 & 3.48 & 35.73 & 0.0014 & 0.8248 & 0.9992 & 1.1310 \\
$\mathrm{PtL}$ & 3.54 & 0.39 & 22.05 & 19.71 & 0.0254 & 0.6380 & 1.1118 & 1.0117 \\
\hline
\end{tabular}

Figure 4 shows the relative chemical composition of the concrete specimen with NS $0.6 \%$ b.w.c. This figure looks contradicting due to the high percentage of silica and a low percentage of calcium. A good percentage of oxides can be due to the reaction of silica with $\mathrm{Ca}(\mathrm{OH})_{2}$ which produces C-S-H gel [11] [12] (Table 7).

\subsection{Comparison Results and Analysis of Mechanical Test}

The change in compressive strength and flexural strength for the blended sample (in \%) for 3, 7 and 28 days is shown respectively in the Table below. A graphical representation of this result is shown respectively in Figure 5 below.

Tables 8-10 show a better increase of compressive strength when we use T01 (without Fly Ash). These observations may be explained by the lower activity factor of $\mathrm{T} 1$ [13]. In fact, the reaction of amorphous silica and alumina phases with $\mathrm{Ca}(\mathrm{OH})_{2}$ leads to the formation of more $\mathrm{CSH}$ [11] [14]. Contrary to compressive strength, we have a loss of flexural strength when we use either T01 or T1 (without Fly Ash). This agrees with the general trend in the literature. In fact concrete is much stronger in compression than it is in tension [15].

The diagrams Figures 5-7 show the real evolution of the mortar compressive strength.

Figure 8 shows that from 3 days to 28 days, the Mortar compressive strenght evolution curve when we use T01 is up all the overs. Then, the appropriate rate of substitution of cement by Titanium Dioxide Nanotube to increase the Mortar compressive strength (without fly ash) is the T01.

Tables 11-13 show the best increase of compressive strength when we use T01 (with Fly Ash). These observations may be explained by the lower activity factor of [13]. In fact, the reaction of amorphous silica and alumina phases with $\mathrm{Ca}(\mathrm{OH})_{2}$ leads to the formation of more $\mathrm{CSH}$ [11] [14].

It is noticed that all the fly ash samples present lower mechanical properties than the discontent fly ash samples. These results are obviously due to a lesser amount of cement in all mixes containing both fly ash and carbon nanotubes [11] [12]. 


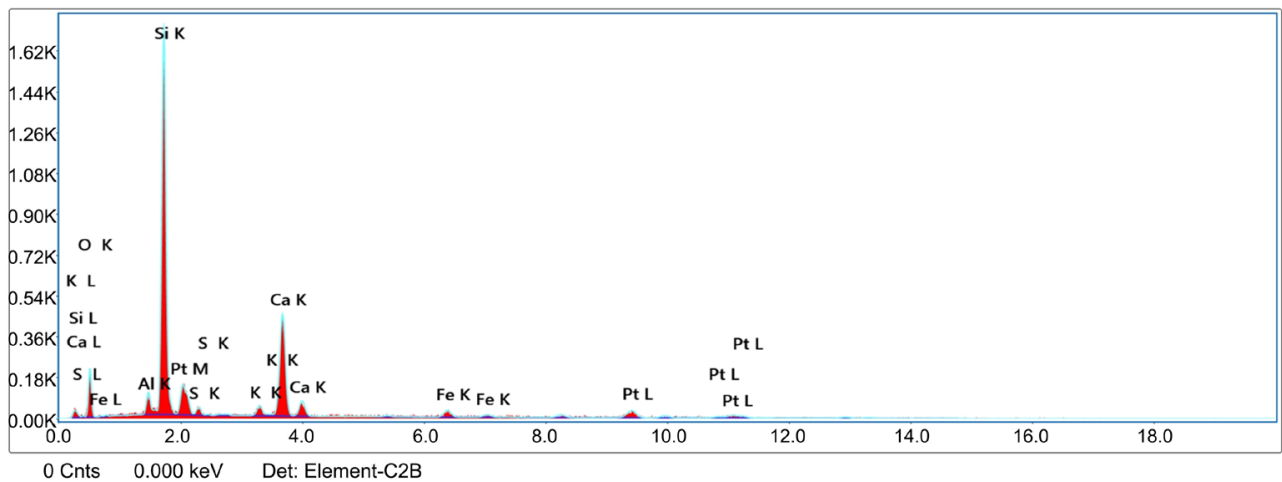

Figure 4. Relative chemical composition for the titanium dioxide specimen.

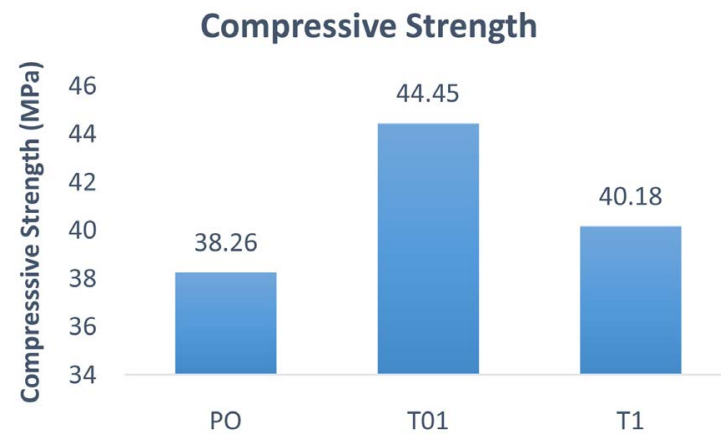

Figure 5. 3-day test mortar specimen without fly ash.

\section{Compressive Strength}

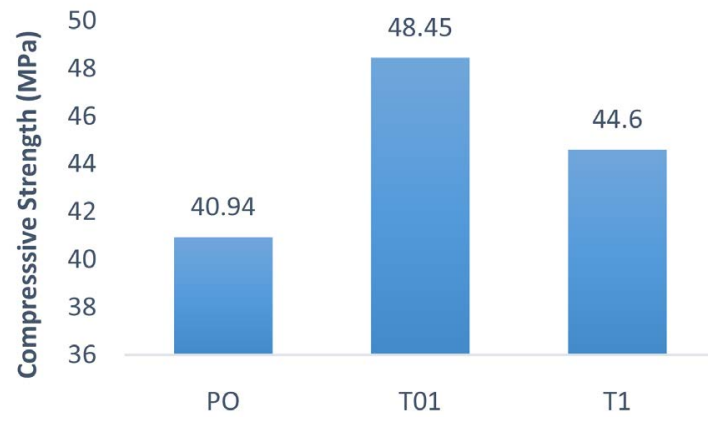

Figure 6. 7-day test mortar specimen without fly ash.

\section{Compressive Strength}

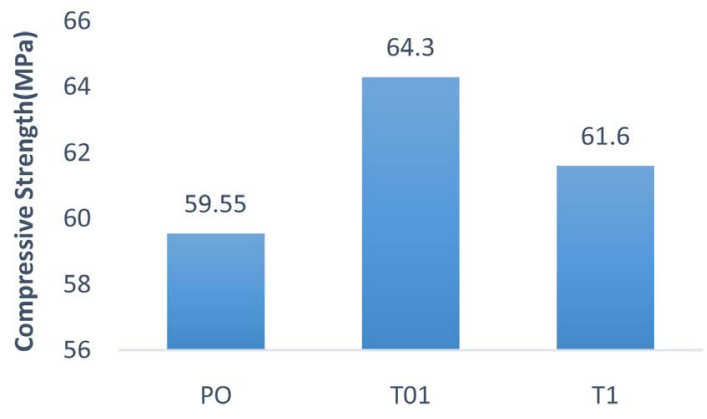

Figure 7. 28-day test mortar specimen without fly ash. 
Table 7. Relative smart quant results for the titanium dioxide specimen.

\begin{tabular}{ccccccccc}
\hline Element & Weight (\%) & Atomic (\%) & Net Int. & Error (\%) & K ratio & Z & A & F \\
\hline O K & 20.10 & 40.19 & 31.24 & 14.88 & 0.0220 & 1.1301 & 0.0969 & 1.0000 \\
$\mathrm{MgK}$ & 1.08 & 1.42 & 7.67 & 24.95 & 0.0027 & 1.0618 & 0.2374 & 1.0013 \\
$\mathrm{AlK}$ & 8.67 & 10.28 & 91.83 & 9.78 & 0.0304 & 1.0259 & 0.3415 & 1.0021 \\
$\mathrm{SiK}$ & 4.44 & 5.06 & 60.12 & 11.26 & 0.0186 & 1.0517 & 0.3982 & 1.0032 \\
$\mathrm{~K} \mathrm{~K}$ & 0.39 & 0.32 & 7.07 & 34.85 & 0.0030 & 0.9878 & 0.7610 & 1.0317 \\
$\mathrm{CaK}$ & 40.22 & 32.11 & 687.10 & 3.34 & 0.3380 & 1.0082 & 0.8244 & 1.0109 \\
$\mathrm{TiK}$ & 0.99 & 0.66 & 13.36 & 20.53 & 0.0065 & 0.9181 & 0.6966 & 1.0236 \\
$\mathrm{FeK}$ & 14.69 & 8.41 & 185.25 & 4.15 & 0.1228 & 0.9126 & 0.8828 & 1.0376 \\
$\mathrm{PtL}$ & 9.42 & 1.54 & 32.69 & 17.90 & 0.0684 & 0.6951 & 1.0517 & 0.9933 \\
\hline
\end{tabular}

Table 8. Comparison mechanical strength of mortar specimen without fly ash at 3-day test.

\begin{tabular}{ccccc}
\hline Type & Flexural & Increase in Strength (\%) & Compressive & Increase in Strength (\%) \\
\hline PO & 8.4 & - & 38.26 & - \\
T01 & 6.9 & -17.85 & 44.45 & 16.19 \\
T1 & 6.27 & -25.36 & 40.18 & 5.03 \\
\hline
\end{tabular}

Table 9. Comparison mechanical strength of mortar specimen without fly ash at 7-day test.

\begin{tabular}{ccccc}
\hline Type & Flexural & Increase in Strength (\%) & Compressive & Increase in Strength (\%) \\
\hline PO & 9.67 & - & 40.94 & - \\
T01 & 8.1 & -16.23 & 48.45 & 18.34 \\
T1 & 7.37 & -23.78 & 44.6 & 8.94 \\
\hline
\end{tabular}

Table 10. Comparison mechanical strength of mortar specimen without fly ash at 28-day test.

\begin{tabular}{ccccc}
\hline Type & Flexural & Increase in Strength (\%) & Compressive & Increase in Strength (\%) \\
\hline PO & 10.1 & - & 59.55 & - \\
T01 & 10.8 & 6.93 & 64.3 & 7.98 \\
T1 & 9.6 & -4.95 & 61.6 & 3.44 \\
\hline
\end{tabular}

Table 11. Comparison mechanical strength of mortar specimen with fly ash at 3-day test.

\begin{tabular}{ccccc}
\hline Type & Flexural & Increase in Strength (\%) & Compressive & Increase in Strength (\%) \\
\hline PO & 6.4 & - & 28.38 & - \\
T01 & 6.03 & -5.78 & 33.17 & 16.88 \\
T1 & 5.97 & -6.72 & 29.99 & 5.66 \\
\hline
\end{tabular}

Table 12. Comparison mechanical strength of mortar specimen with fly ash at 7-day test.

\begin{tabular}{ccccc}
\hline Type & Flexural & Increase in Strength (\%) & Compressive & Increase in Strength (\%) \\
\hline PO & 7.53 & - & 31.98 & - \\
T01 & 7.43 & -1.33 & 37.85 & 18.36 \\
T1 & 7.36 & -2.26 & 34.84 & 8.96 \\
\hline
\end{tabular}


Table 13. Comparison mechanical strength of mortar specimen with fly ash at 28-day test.

\begin{tabular}{ccccc}
\hline Type & Flexural & Increase in Strength (\%) & Compressive & Increase in Strength (\%) \\
\hline PO & 9.5 & - & 54.14 & - \\
T01 & 9.2 & -3.16 & 58.45 & 7.98 \\
T1 & 9.23 & -2.84 & 56.51 & 4.39 \\
\hline
\end{tabular}

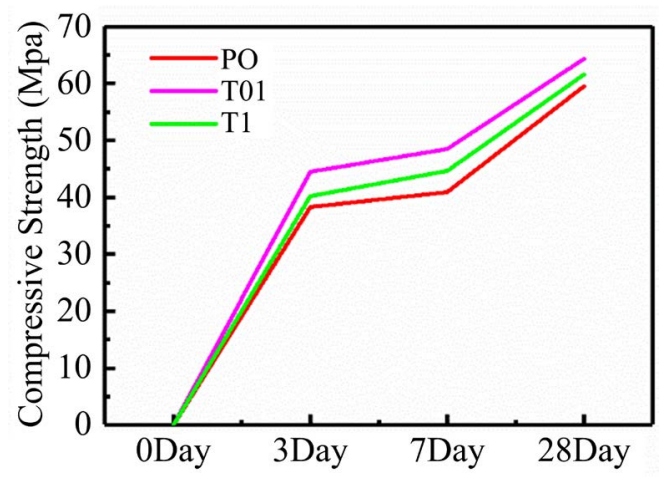

Figure 8. Change in compressive strength of mortar specimen without fly ash from 3 days to 28 days.

Contrary to compressive strength, we have a loss of flexural strength when we use either T01 or T1 (with Fly Ash). This agrees with the general trend in the literature. In fact concrete is much stronger in compression than it is in tension [15].

The diagrams Figures 9-11 show the real evolution of the Mortar compressive strength.

Figure 12 shows that, from 3 days to 28 days, the Mortar compressive strength evolution curve when we use T01 is up to all the overs. Then, the appropriate rate of substitution of cement by Titanium Dioxide Nanotube to increase the Mortar compressive strength (with fly ash) is the T01. We remark that Mortar specimens are gaining in mechanical characteristics while gaining in age. This agrees with the literature.

Tables 14-16 show a better increase of compressive strength when we use T01 (without Fly Ash). These observations may be explained by the lower activity factor of $\mathrm{T} 1$ [13]. In fact, the reaction of amorphous silica and alumina phases with $\mathrm{Ca}(\mathrm{OH})_{2}$ leads to the formation of more CSH [10] [13]. Contrary to compressive strength, we have a loss of flexural strength when we use either T01 or T1 (without Fly Ash). This agrees with the general trend in the literature [15].

The diagrams Figures 13-15 show the real evolution of the Cement Paste compressive strength.

Figure 16 shows that, from 3 days to 28 days, the Cement Paste compressive strength evolution curve when we use T01 is up to all the overs. Then, the appropriate rate of substitution of cement by Titanium Dioxide Nanotube to increase the Cement Paste compressive strength (without fly ash) is the T01. 


\section{Compressive Strength}

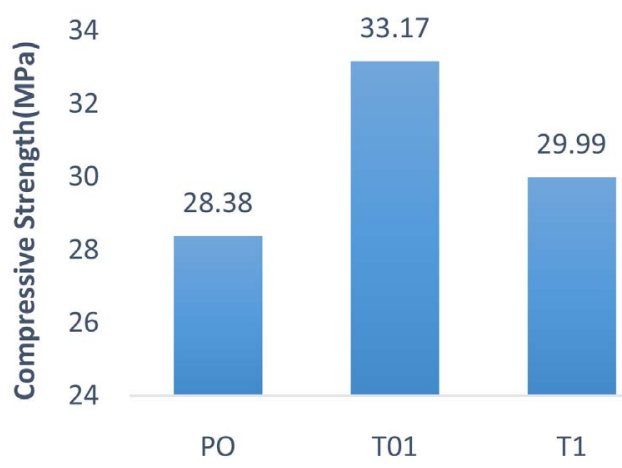

Figure 9. 3-day test mortar specimen with fly ash.

\section{Compressive Strength}

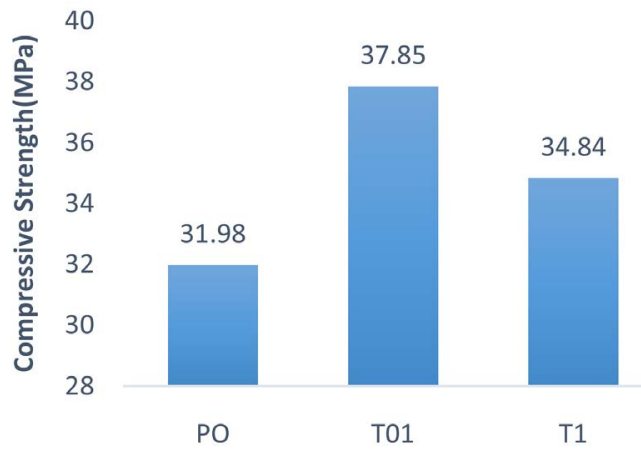

Figure 10. 7-day test mortar specimen with fly ash.

\section{Compressive Strength}

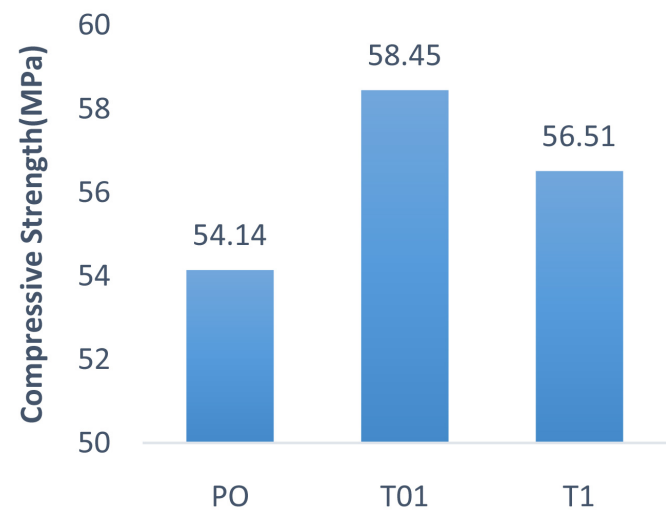

Figure 11.28-day test mortar specimen with fly ash.

Table 14. Comparison mechanical strength of cement paste specimen without fly ash at 3-day test.

\begin{tabular}{ccccc}
\hline Type & Flexural & Increase in Strength (\%) & Compressive & Increase in Strength (\%) \\
\hline PO & 7.5 & - & 38.6 & - \\
T01 & 9.6 & 28.00 & 47.35 & 22.67 \\
T1 & 8.2 & 9.33 & 42.7 & 10.62 \\
\hline
\end{tabular}


Table 15. Comparison mechanical strength of cement paste specimen without fly ash at 7-day test.

\begin{tabular}{ccccc}
\hline Type & Flexural & Increase in Strength (\%) & Compressive & Increase in Strength (\%) \\
\hline PO & 8.4 & - & 41.68 & - \\
T01 & 10.5 & 25.00 & 51.74 & 24.15 \\
T1 & 9.5 & 13.10 & 47.52 & 14.02 \\
\hline
\end{tabular}

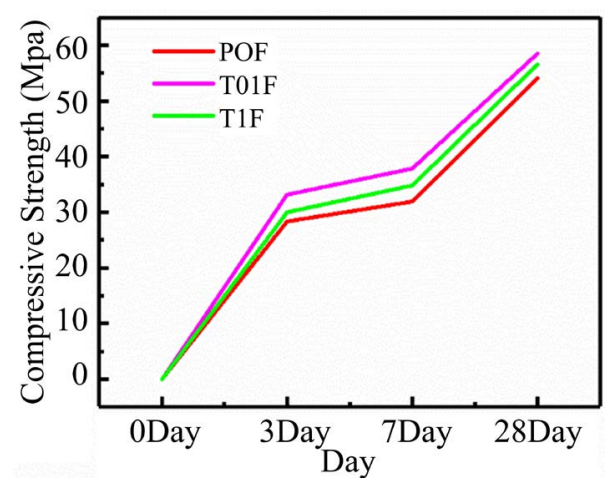

Figure 12. Change in compressive strength of mortar specimen with fly ash from 3 days to 28 days.

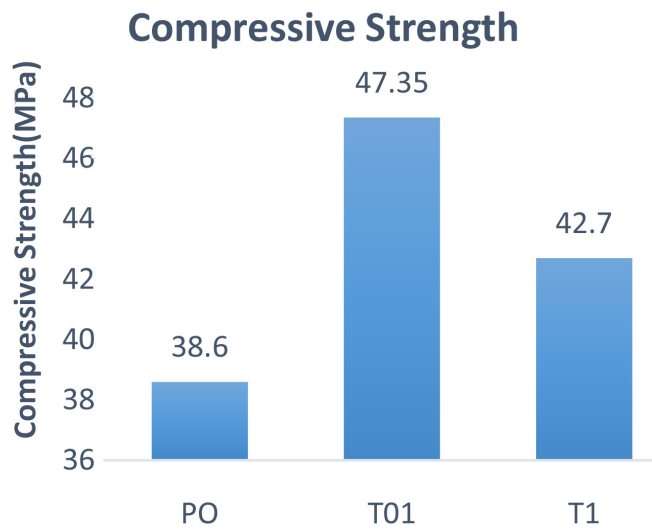

Figure 13. 3-day test cement paste specimen without fly ash.

\section{Compressive Strength}

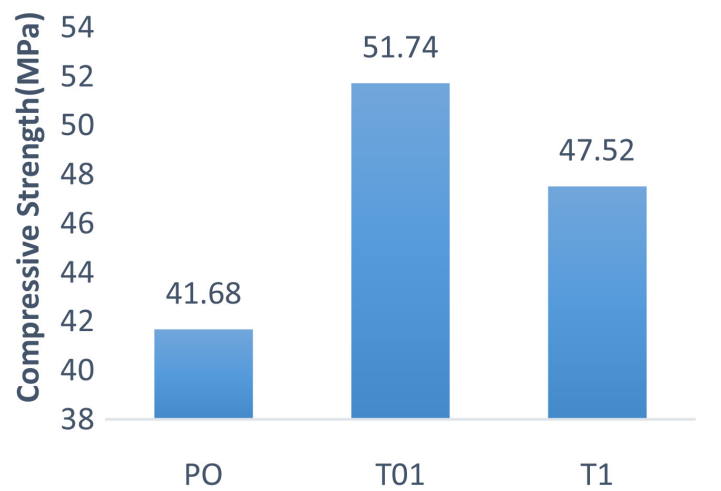

Figure 14. 7-day test cement paste specimen without fly ash. 
Table 16. Comparison mechanical strength of cement paste specimen without fly ash at 28-day test.

\begin{tabular}{ccccc}
\hline Type & Flexural & Increase in Strength (\%) & Compressive & Increase in Strength (\%) \\
\hline PO & 9.9 & - & 63.6 & - \\
T01 & 12.2 & 23.23 & 68.2 & 7.17 \\
T1 & 11.4 & 15.15 & 65.3 & 2.67 \\
\hline
\end{tabular}

\section{Compressive Strength}

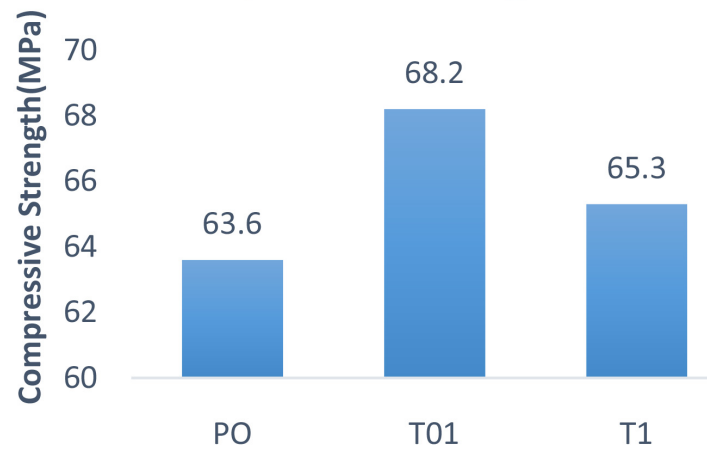

Figure 15. 28-day test cement paste specimen without fly ash.

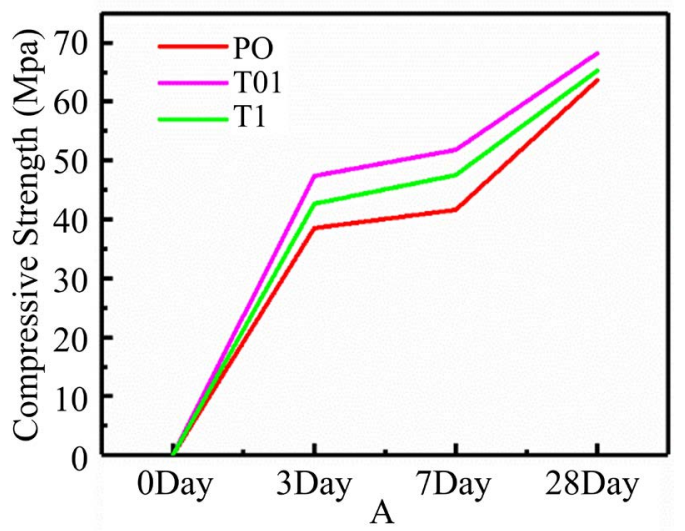

Figure 16. Change in compressive strength of cement paste specimen without fly ash from 3 days to 28 days.

Tables 17-19 show the best increase of compressive strength when we use T01 (with Fly Ash). These observations may be explained by the lower activity factor of $\mathrm{T} 1$ [13]. In fact, the reaction of amorphous silica and alumina phases with $\mathrm{Ca}(\mathrm{OH})_{2}$ leads to the formation of more $\mathrm{CSH}$ [11] [14].

It is noticed that all the fly ash samples present lower mechanical properties than the discontent fly ash samples. These results are obviously due to a lesser amount of cement in all mixes containing both fly ash and carbon nanotubes [11] [12].

Contrary to compressive strength, we have a loss of flexural strength when we use either T01 or T1 (with Fly Ash). This agrees with the general trend in the literature because cementitious materials are much stronger in compression than 
they are in tension [15].

The diagrams Figures 17-19 show the real evolution of the Cement Paste compressive strength.

Figure 20 shows that, from 3 days to 28 days, the Cement Paste compressive strength evolution curve when we use T01 is up all the overs. Then, the appropriate rate of substitution of cement by Titanium Dioxide Nanotube to increase the Cement Paste compressive strength (with fly ash) is the T01.

Table 17. Comparison mechanical strength of cement paste specimen with fly ash at 3-day test.

\begin{tabular}{ccccc}
\hline Type & Flexural & Increase in Strength (\%) & Compressive & Increase in Strength (\%) \\
\hline PO & 6.5 & - & 28.9 & - \\
T01 & 8 & 23.08 & 33.8 & 17.11 \\
T1 & 7.2 & 10.77 & 30.5 & 5.66 \\
\hline
\end{tabular}

Table 18. Comparison mechanical strength of cement paste specimen with fly ash at 7-day test.

\begin{tabular}{ccccc}
\hline Type & Flexural & Increase in Strength (\%) & Compressive & Increase in Strength (\%) \\
\hline PO & 7.9 & - & 43.2 & - \\
T01 & 8.6 & 8.86 & 51.1 & 18.36 \\
T1 & 8.9 & 12.66 & 47.0 & 8.96 \\
\hline
\end{tabular}

Table 19. Comparison mechanical strength of cement paste specimen with fly ash at 28-day test.

\begin{tabular}{ccccc}
\hline Type & Flexural & Increase in Strength (\%) & Compressive & Increase in Strength (\%) \\
\hline PO & 9 & - & 55.8 & - \\
T01 & 11.2 & 24.44 & 60.2 & 7.98 \\
T1 & 10.5 & 16.67 & 58.2 & 4.39 \\
\hline
\end{tabular}

\section{Compressive Strength}

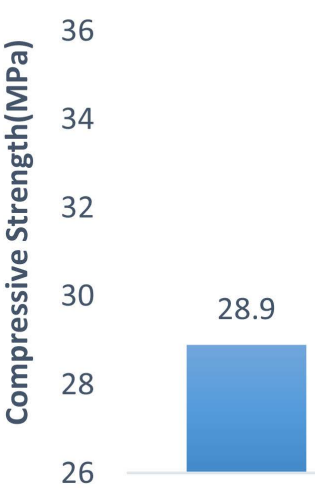

PO

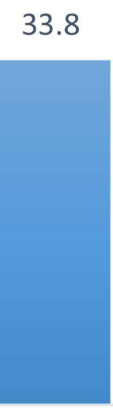

T01

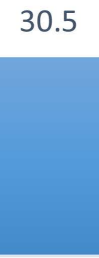

T1

Figure 17. 3-day test cement paste specimen with fly ash. 


\section{Compressive Strength}

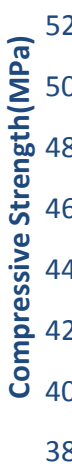

51.1

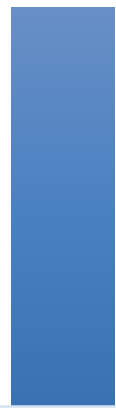

47

43.2

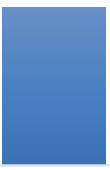

$\mathrm{PO}$

T01

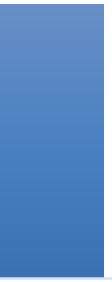

T1

Figure 18. 7-day test cement paste specimen with fly ash.

\section{Compressive Strength}

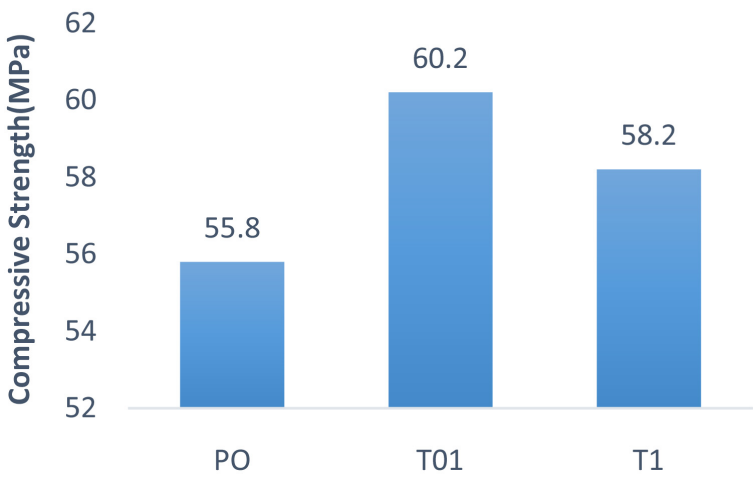

Figure 19. 28 days test cement paste specimen with fly ash.

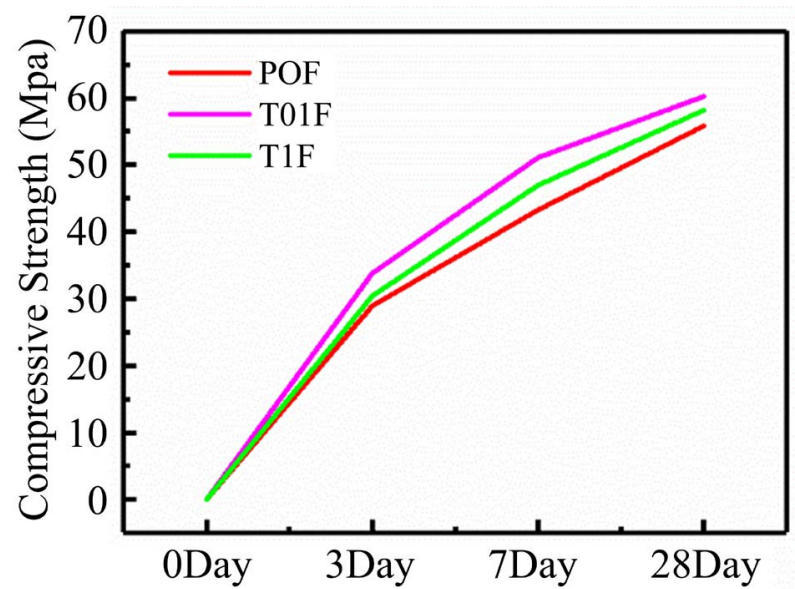

Figure 20. Change in compressive strength of cement paste specimen with fly ash from 3 days to 28 days.

\section{Conclusion}

The use of Titanium Dioxides offers interesting results when the purpose is to increase the compressive strength of the cementitious materials; specially the use 
of the T01 gives very good results in compressive strength increasing it for all the cases. However, using Titanium Dioxide Nanotubes provides a light negative effect on flexural strength. But using titanium dioxide and fly ash shows bad results either for compressive strength or flexural strength because of the lesser amount of binder comparing to the case of using titanium dioxide T01 alone.

\section{Conflicts of Interest}

The authors declare no conflicts of interest regarding the publication of this paper.

\section{References}

[1] Taylor, H.F.W. (1997) 1 Portland Cement and Its Major Constituent Phases. In: Telford, T., Ed., Cement Chemistry, Thomas Telford Publishing, UK. https://doi.org/10.1680/cc.25929.0001

[2] Saleh, H.M. and Eskander, S.B. (2020) Innovative Cement-Based Materials for Environmental Protection and Restoration. In: Samui, P., Kim, D., Iyer, N.R. and Chaudhary, S., Eds., New Materials in Civil Engineering, Butterworth-Heinemann, UK, 613-641. https://doi.org/10.1016/B978-0-12-818961-0.00018-1

[3] Michaux, M., Nelson, E.B. and Vidick, B. (1990) 2 Chemistry and Characterization of Portland Cement. Developments in Petroleum Science, 28, 2-1-2-17. https://doi.org/10.1016/S0376-7361(09)70300-0

[4] Amato, I. (2013) Green Cement: Concrete Solutions. Nature News, 494, 300-301. https://doi.org/10.1038/494300a

[5] Beck-Broichsitter, M., Thieme, M., Nguyen, J., Schmehl, T., Gessler, T., Seeger, W., Agarwal, S., Greiner, A. and Kissel, T. (2010) Novel "Nano in Nano" Composites for Sustained Drug Delivery: Biodegradable Nanoparticles Encapsulated into Nanofiber Non-Wovens. Macromolecular Bioscience, 10, 1527-1535. https://doi.org/10.1002/mabi.201000100

[6] Liu, C.J., Huang, X.C., Wu, Y.-Y., Deng, X.W., Liu, J., Zheng, Z.L. and Hui, D. (2020) Review on the Research Progress of Cement-Based and Geopolymer Materials Modified by Graphene and Graphene Oxide. Nanotechnology Reviews, 9, 155 169. https://doi.org/10.1515/ntrev-2020-0014

[7] Deni, S., Tambunan, R., Waruwu, A. and Syamsuddin, M. (2018) Studies on Concrete by Partial Replacement of Cement with Volcanic Ash. Journal of Applied Engineering Science, 16, 161-165. https://doi.org/10.5937/jaes16-16494

[8] Hossain, M.M., Karim, M.R., Hossain, M.K., Islam, M.N. and Zain, M.F.M. (2015) Durability of Mortar and Concrete Containing Alkali-Activated Binder with Pozzolans: A Review. Construction and Building Materials, 93, 95-109. https://doi.org/10.1016/j.conbuildmat.2015.05.094

[9] (2018) 2-Development, Testing, and Numerical Simulation of Ultra-High Performance Concrete at Material Level. In: Wu, C.Q., Li, J. and Su, Y., Eds., Development of Ultra-High Performance Concrete Against Blasts, Woodhead Publishing, 23-93. https://doi.org/10.1016/B978-0-08-102495-9.00002-5

[10] Gonzalez-Corominas, A., Etxeberria, M. and Poon, C.S. (2016) Influence of Steam Curing on the Pore Structures and Mechanical Properties of Fly-Ash High Performance Concrete Prepared with Recycled Aggregates. Cement and Concrete Composites, 71, 77-84. https://doi.org/10.1016/j.cemconcomp.2016.05.010 
[11] Khan, K., Amin, M.N., Saleem, M.U., Qureshi, H.J., Al-Faiad, M.A. and Qadir, M.G. (2019) Effect of Fineness of Basaltic Volcanic Ash onPozzolanic Reactivity, ASR Expansion and DryingShrinkage of Blended Cement Mortars. Materials, 12, Aticle No. 2603. https://doi.org/10.3390/ma12162603

[12] Zineb, D. and Merzoud, M. (2018) Effect of Mineral Admixtures on the Rheological and Mechanical Properties of Mortars. MATEC Web of Conferences, 149, Article No. 01066. https://doi.org/10.1051/matecconf/201714901066

[13] Munch-Petersen, G.N. and Meson, V.M. (2015) Evaluation of Mechanical Properties of Concrete. Concrete: Innovation and Design, Copenhagen, May 18-20, 2015, $14 \mathrm{p}$.

[14] Shi, C.j. and Day, R. (2001) Comparison of Different Methods for Enhancing Reactivity of Pozzolans. Cement and Concrete Research, 31, 813-818. https://doi.org/10.1016/S0008-8846(01)00481-1

[15] O’Neil, E.F., Neeley, B.D. and Cargile, J.D. (1999) Tensile Properties of Very-HighStrength Concrete for Penetration-Resistant Structures. Shock and Vibration, 6, 237 245. https://doi.org/10.1155/1999/415360 